\title{
Pembentukan ubi mikro kentang (Solanum tuberosum L.) pada berbagai komposisi media in vitro
}

\section{The formation of potato micro tuber (Solanum tuberosum L.) in different medium composition using in vitro}

Diterima : 11 Desember 2017/Disetujui : 18 Desember 2017 / Dipublikasikan : 30 Desember 2017

CDepartment of Crop Science, Padjadjaran University

\begin{abstract}
The common issues related to the potato production are the limitation and availability of quality seeds as well as seed deterioration. This study aimed to determine the medium composition for plant growth and the formation of micro-tubers from in vitro culture to get the high quality of potato seed. This experiment was conducted at Tissue Culture Technology Laboratory, Faculty of Agriculture, Universitas Padjadjaran Jatinangor, Sumedang, from October 2015 to May 2016. Randomized coplete design was used in this experiment with the combination of two kind's of basal medium (MS and MS modification). Moreover, we used three levels plant growth inhibitors (coumarin $105 \mathrm{mg} \mathrm{L}^{-1}$ and $120 \mathrm{mg} \mathrm{L}^{-1}$; paclobutrazol $0.4 \mathrm{mg}$ $\mathrm{L}^{-1}$ and $\left.1 \mathrm{mg} \mathrm{L}^{-1}\right)$; three levels of jasmonic acid $\left(0,4 \mathrm{mg} \mathrm{L}^{-1}\right.$ and $\left.10 \mathrm{mg} \mathrm{L}^{-1}\right)$; and two levels of sugar $\left(90 \mathrm{~g} \mathrm{~L}^{-1}\right.$ and $\left.120 \mathrm{gL}^{-1}\right)$ and it were repeated five times. The results showed that $B$ treatment (paclobutrazol) affect on the fresh weight potato micro-tuber. while the jasmonic acid affect on plantlet microtuber formation percentage.
\end{abstract}

Keywords: potato microtubers, plant growth inhibitors, paclobutrazol, jasmonic acid, coumarin

Sari Permasalahan umum terkait pada produksi kentang adalah penggunaan benih sumber yang kurang bermutu dan mengalami kemunduran benih. Penelitian bertujuan mendapatkan komposisi media yang optimum untuk produksi ubi mikro kentang secara in vitro sehingga dapat

\footnotetext{
Dikomunikasikan oleh Wawan Sutari

${\text { Amalia, I. }{ }^{1} \cdot \text { A. Nuraini }}^{2} \cdot$ Sumadi $^{2} \cdot$ S. Mubarok ${ }^{2} \cdot$ E. Suminar ${ }^{2}$

${ }^{1}$ Mahasiswa Program Studi Agroteknologi, Fakultas

Pertanian, Universitas Padjadjaran

${ }^{2}$ StafPengajarDepartemen Budidaya Pertanian, Fakultas

Pertanian, Universitas Padjadjaran

Korespondensi: erni.suminar@unpad.ac.id.
}

digunakan untuk penyediaan bibit berkualitas. Percobaan dilaksanakan di Laboratorium Kultur Jaringan Teknologi Benih Fakultas Pertanian Universitas Padjadjaran Jatinangor, Sumedang, pada bulan Oktober 2015 sampai Mei 2016. Metode percobaan yang digunakan adalah Rancangan Acak Lengkap (RAL) yang merupakan kombinasi dari media, retardan coumarin $(105 \mathrm{mg}$ $\mathrm{L}^{-1}$ dan $\left.120 \mathrm{mg} \mathrm{L}^{-1}\right)$, paklobutrazol $\left(0.4 \mathrm{mg} \mathrm{L}^{-1}\right.$ dan 1 $\left.\mathrm{mg} \mathrm{L}^{-1}\right)$ dan jasmonic acid $\left(0,4 \mathrm{mg} \mathrm{L}^{-1}\right.$ dan $10 \mathrm{mg} \mathrm{L}^{-}$ $\left.{ }^{1}\right)$, dan tambahan gula dengan komposisi $90 \mathrm{~g} \mathrm{~L}^{-1}$ dan $120 \mathrm{gL}^{-1}$. Percobaan diulang sebanyak lima kali. Hasil penelitian menunjukkan bahwa perlakuan B (MS + paclobutrazol $1 \mathrm{mg} \cdot \mathrm{L}^{-1}+$ gula $120 \mathrm{mg}^{\left.-\mathrm{L}^{-1}\right)}$ menunjukkan hasil yang lebih baik terhadap persentase plantlet membentuk ubi miko, jumlah ubi mikro yang terbentuk dan bobot ubi mikro kentang.

Kata Kunci: ubi mikro kentang, zat penghambat tumbuh, paclobutrazol, jasmonic acid, coumarin

\section{Pendahuluan}

Kentang (Solanum tuberosum L.) merupakan salah satu komoditas yang menjadi pendukung ketahanan pangan, namun hingga saat ini produktivitasnya masih rendah dikarenakan masih rendahnya penggunaan benih kentang bermutu oleh petani (Sayaka \& Hestina 2001), dalam hal ini petani menggunakan benih produksi sendiri atau benih impor yang sudah turun temurun beberapa generasi sehingga daya hasilnyarendah (Soegihartono, 2005). Penyebab dari rendahnya keterbatasan benih bermutu adalah masih rendahnya ketersediaan benih kentang bersertifikat, pada umumnya petani masih menggunakan benih kentang sendiri, serta pengaruh anomali iklim yang menyebabkan 
suhu tidak menentu dan berpengaruh terhadap pertumbuhan tanaman kentang (Ilyas, 2008).

Menurut Karjadi dan Buchory (2008), kultur meristem merupakan salah satu teknik perbanyakan in vitro yang dilakukan untuk mendapatkan tanaman bebas penyakit sistemik, terutama virus dari tanaman yang terinfeksi. Plantlet yang terbentuk dari kultur meristem, selanjutnya dilakukan induksi ubi mikro yang dapat dijadikan Ubi sebagai solusi penyediaan benih sumber kentang bermutu.

Permintaan komoditas kentang setiap tahunnya mengalami peningkatan, sehingga diperlukan penambahan luas areal penanaman kentang, hal ini akan memerlukan jumlah benih kentang bermutu yang cukup tinggi. Penggunaan ubi mikro telah dicoba untuk digunakan sebagai sumber benih, namun masih diperlukan metode dalam memproduksinya secara in vitro. Menurut Wattimena (1988), pembentukan ubi mikro kentang secara in vitro dapat dipercepat dengan penambahan zat penghambat tumbuh (retardan).-Retardan yang dapat digunakan untuk menginduksi ubi mikro kentang secara in vitro, diantaranya coumarin, paclobutrazol dan jasmonic acid (Hoque, 2010).

Hasil penelitian menunjukkan bahwa peningkatan konsentrasi coumarin dapat menghasilkan ubi mikro dalam ukuran yang lebih besar (Kianmehr et al. 2012), paklobutrazol mempengaruhi terhadap bobot ubi mikro (Macwan et al. 2016) dan penggunaan jasmonic acid dapat mempercepat dan menghasilkan bobot ubi mikro yang lebih besar (Suminar et al. 2016).

Peningkatan konsentrasi paklobutrazol hingga $0.4 \mathrm{mg} . \mathrm{L}^{-1}$ dapat meningkatkan jumlah ubi mikro kentang yang terbentuk, namun konsentrasi yang lebih tinggi menyebabkan jumlah ubi mikro kentang mengalami penurunan (Samanhudi dkk., 2002). Jasmonic acid (JA) berperan sebagai regulator pertumbuhan tanaman (Ulloa et al., 2002), mempengaruhi pertumbuhan dan perkembangan tanaman, serta penghambatan perkecambahan biji (Huang et al., 2002). Penggunaan jasmonic acid pada konsentrasi $0,4 \mathrm{mg} \cdot \mathrm{L}^{-1}$ dan $10 \mathrm{mg} \cdot \mathrm{L}^{-1}$ merupakan konsentrasi yang cukup signifikan (Zhang, 2006), senyawa pengatur yang mempengaruhi respon dan signal tumbuhan yang bekerja dalam proses penghambatan dan berperan dalam pembentukan ubi mikro (Rorbertet al., 2007). Pembentukan ubi mikro juga dipengaruhi oleh kandungan gula dalam media. Pembentukan ubi mikro meningkat dengan penambahan konsen-trasi gula (Saha et al., 2013).

\section{Bahan dan Metode}

Percobaan dilaksanakan di Laboratorium Kultur Jaringan Teknologi Benih Fakultas Pertanian Universitas Padjadjaran di Jatinangor, Sumedang. Percobaan dilakukan terdiri dari dua tahap, yaitu tahap pendahuluan yang dilaksanakan pada bulan Oktober 2015 - Januari 2016 dan tahap perlakuan yang dilaksanakan pada bulan Februari 2016 - Mei 2016.

Bahan yang digunakan adalah stek in vitro kentang kultivar Jala Ipam. Media yang digunakan adalah media MS dan MS modifikasi dengan tambahan vitamin, zat retardan (paklobutrazol, coumarin, jasmonic acid). Alatalat yang digunakan pada tahap persiapan adalah timbangan analitik, beaker glass, pipet, $\mathrm{pH}$ meter, labu erlenmeyer, pengaduk magnetik, kompor listrik, botol kultur, autoclave, dan lemari es. Alat-alat yang dibutuhkan pada tahap penanaman alat-alat yang dibutuhkan antara lain adalah Laminar Air Flow (LAF), cawan petri, pinset, scalpel, handsprayer, dan lampu spirtus. Alat alat yang dibutuhkan pada tahap inubasi adalah rak kultur, Air Conditioner (AC), Lampu.

Penelitian ini menggunakan metode eksperimen dengan Rancangan Acak Lengkap (RAL) yang terdiri dari 12 perlakuan kombinasi media pembentukan ubi mikro kentang diulang sebanyak lima kali serta masing-masing ulangan terdiri dari dua unit botol kultur, 1 botol terdiri dari 4 eksplan sehingga terdapat 480 eksplan dengan perincian perlakuan sebagai berikut:

$\mathrm{A}=\mathrm{MS}+$ paclobutrazol $0.4 \mathrm{mg} . \mathrm{L}+$ gula $90 \mathrm{~g} \cdot \mathrm{L}^{-1}$

$\mathrm{B}=\mathrm{MS}+$ paclobutrazol $1 \mathrm{mg} \cdot \mathrm{L}^{-1}+$ gula120 g. $\mathrm{L}^{-1}$

$\mathrm{C}=\mathrm{MS}+$ jasmonic acid $0.4 \mathrm{mg} . \mathrm{L}^{-1}+$ gula 90 g.L $\mathrm{L}^{-1}$

$\mathrm{D}=\mathrm{MS}+$ jasmonic acid $10 \mathrm{mg} . \mathrm{L}^{-1}+$ gula120 g.L-1

$\mathrm{E}=\mathrm{MS}+$ coumarin $105 \mathrm{mg} \cdot \mathrm{L}^{-1}+$ gula $90 \mathrm{~g} . \mathrm{L}^{-1}$

$\mathrm{F}=\mathrm{MS}+$ coumarin $120 \mathrm{mg} \cdot \mathrm{L}^{-1}+$ gula120 g. $\mathrm{L}^{-1}$

$\mathrm{G}=$ MS modifikasi + paklobutrazol $0,4 \mathrm{mg} \cdot \mathrm{L}^{-1}+$ gula 90 g.L-1

$\mathrm{H}=$ MS modifikasi + paklobutrazol $1 \mathrm{mg} \cdot \mathrm{L}^{-1}+$ gula 120 g.L.-1

$\mathrm{I}=$ MS modifikasi + jasmonic acid $0,1 \mathrm{mg} \cdot \mathrm{L}^{-1}+$ gula 90 g.L-1

$\mathrm{J}=$ MS modifikasi + jasmonic acid $10 \mathrm{mg} \cdot \mathrm{L}^{-1+}$ gula120 g.L-1

$\mathrm{K}=$ MS modifikasi + coumarin $105 \mathrm{mg} \cdot \mathrm{L}^{-1}+$ gula 90 g.L-1

$\mathrm{L}=$ MS modifikasi + coumarin 120 mg. $\mathrm{L}^{-1+}$ gula120 g.L-1

Media yang digunakan diantaranya media

MS dan MS modifikasi (diberi tambahan 
vitamin). Tahap inisiasi tunas : media MS dengan penambahan gula 30 g.L. $\mathrm{L}^{-1}$, Myoinositol 100 mg.L $\mathrm{L}^{-1}$, Casein Hidrolisat 20 mg.L $\mathrm{L}^{-1}$, Thiamin $\mathrm{HCl}$ 0,1 mg.L-1, 1,0 mg.L-1 Pyridoxin $\mathrm{HCl}, 0,5$ $\mathrm{mg} / \mathrm{L}^{-1}$ nicotinic acid, $2 \mathrm{mg} . \mathrm{L}^{-1} \mathrm{BAP}$ dan $1 \mathrm{mg} \cdot \mathrm{L}^{-1}$ NAA dan dicampurkan agar sebanyak 8 g.L-1 serta aquades steril. Media yang telah dicampurkan diukur dengan $\mathrm{pH}$ meter dengan nilai 5,8. Tahap Induksi Ubi Mikro : media yang digunakan media MS dan MS modifikasi cair

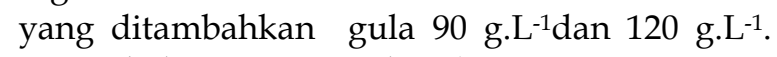
Penambahan zat retardan (coumarin, jasmonic acid dan paclobutrazol) dibuat sesuai perlakuan. Media pengumbian diaplikasi pada saat plantlet berumur 4 MST dalam media inisiasi tunas, kemudian menuangkan media cair sesuai perlakuan sebanyak $10 \mathrm{ml}$ dan menyimpannya di ruang kultur pada kondisi gelap dengan suhu 20-22 ${ }^{\circ} \mathrm{C}$ (Karjadi dan Buchory, 2008).

Pengamatan dilakukan terhadap persentase planlet yang membentuk ubi mikro, ratarata jumlah ubi mikro kentang yang terbentuk pada waktu 4MST, 8MST, 12 MST dan bobot ubi mikro kentang yang diamati pada 12 MST.

\section{Hasil dan Pembahasan}

Persentase Planlet Membentuk Ubi Mikro. Berdasarkan hasil analisis ragam persentase planlet yang membentuk ubi mikro menunjukkan hasil tidak berbeda nyata, namun pemberian jasmonic acid $10 \mathrm{mg} \cdot \mathrm{L}^{-1}$ dan gula 120 g.L-1 pada media MS menunjukkan persentase plantlet yang cenderung lebih baik daripada perlakuan lainnya terhadap persentase plantlet membentuk ubi mikro (Tabel 1).

Perlakuan L dengan penambahan coumarin pada konsentrasi yang tinggi yaitu $120 \mathrm{mg} \mathrm{L}^{-1} \mathrm{dan}$ gula $120 \mathrm{~g} \mathrm{~L} \mathrm{~L}^{-1}$ memiliki persentase eksplan membentuk ubi mikro yang rendah hanya $50 \%$ (Tabel 1).

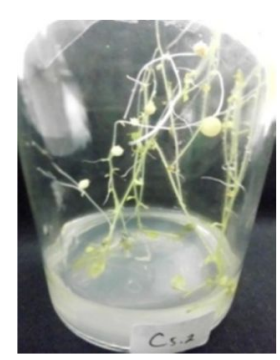

(A)

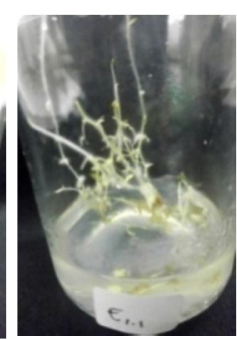

(B)

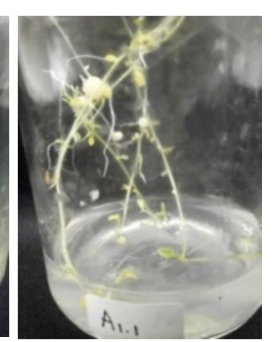

(C)
Gambar 2. (A) Pemberian jasmonic acid ; (B) Pemberian paklobutrazol; $\quad$ (C) Pemberian coumarin
Tabel 1. Persentase Planlet Membentuk Ubi Mikro.

\begin{tabular}{cc}
\hline Perlakuan & $\begin{array}{c}\text { Persentase planlet membentuk } \\
\text { ubi mikro (\%) }\end{array}$ \\
\hline A & $72,50 \mathrm{a}$ \\
B & $67,50 \mathrm{a}$ \\
C & $80,00 \mathrm{a}$ \\
D & $92,50 \mathrm{a}$ \\
E & $80,00 \mathrm{a}$ \\
F & $87,50 \mathrm{a}$ \\
G & $80,00 \mathrm{a}$ \\
H & $62,50 \mathrm{a}$ \\
I & $65,00 \mathrm{a}$ \\
J & $62,50 \mathrm{a}$ \\
K & $75,00 \mathrm{a}$ \\
L & $50,00 \mathrm{a}$ \\
\hline
\end{tabular}

Keterangan: Nilai rata-rata perlakuan yang diikuti oleh huruf yang sama dan pada kolom yang sama menunjukkan tidak berbeda nyata berdasarkan uji jarak berganda Duncan pada taraf $5 \%$.

Jumlah Ubi Mikro. Perlakuan jenis media, jenis retardan dan konsentrasi gula berpengaruh nyata terhadap jumlah ubi mikro pada 4 MST, 8MST dan 12 MST (Tabel 2.).

Tabel 2. Pengaruh Berbagai Kombinasi Zat Retardan terhadap Jumlah Ubi yang Terbentuk.

\begin{tabular}{crrr}
\hline \multirow{2}{*}{ Perlakuan } & \multicolumn{4}{c}{ Jumlah Ubi Yang Terbentuk } \\
\cline { 2 - 4 } & 4 MST & 8 MST & $12 \mathrm{MST}$ \\
\hline A & $0,68 \mathrm{~cd}$ & $1,00 \mathrm{ab}$ & $1,20 \mathrm{abc}$ \\
$\mathrm{B}$ & $0,78 \mathrm{abc}$ & $1,18 \mathrm{a}$ & $1,23 \mathrm{ab}$ \\
$\mathrm{C}$ & $0,98 \mathrm{abc}$ & $1,33 \mathrm{a}$ & $1,33 \mathrm{ab}$ \\
$\mathrm{D}$ & $0,97 \mathrm{abc}$ & $1,33 \mathrm{a}$ & $1,53 \mathrm{ab}$ \\
$\mathrm{E}$ & $0,72 \mathrm{abc}$ & $1,00 \mathrm{a}$ & $1,10 \mathrm{abc}$ \\
$\mathrm{F}$ & $1,00 \mathrm{ab}$ & $1,55 \mathrm{a}$ & $1,73 \mathrm{a}$ \\
$\mathrm{G}$ & $1,13 \mathrm{a}$ & $1,23 \mathrm{a}$ & $1,43 \mathrm{ab}$ \\
$\mathrm{H}$ & $0,78 \mathrm{abc}$ & $0,83 \mathrm{ab}$ & $0,83 \mathrm{bc}$ \\
$\mathrm{I}$ & $0,98 \mathrm{abc}$ & $1,18 \mathrm{a}$ & $1,18 \mathrm{ab}$ \\
$\mathrm{J}$ & $0,83 \mathrm{abc}$ & $0,90 \mathrm{ab}$ & $1,00 \mathrm{abc}$ \\
K & $0,53 \mathrm{bcd}$ & $0,98 \mathrm{ab}$ & $1,05 \mathrm{abc}$ \\
L & $0,35 \mathrm{~d}$ & $0,60 \mathrm{~b}$ & $0,63 \mathrm{c}$ \\
\hline
\end{tabular}

Keterangan: Nilai rata-rata perlakuan yang diikutiolehhuruf yang dan pada kolom yang sama menunjukkan tidak berbeda nyata berdasarkan uji jarak berganda Duncan pada taraf $5 \%$.

Tabel 2 menunjukkan bahwa pada 4 MST hingga 12 MST, penggunaan media dasar MS menghasilkan rata-rata jumlah ubi yang terbentuk lebih tinggi daripada penggunaan media MS modifikasi. Penggunaan media dasar MS banyak digunakan untuk induksi ubi mikro (Kanwal et al.2006). Inhibitor coumarin dan jasmonic acid menghasilkan rata-rata jumlah ubi mikro yang 
lebih besar walaupun tidak berbeda nyata dengan perlakuan lainnya, tetapi pada penggunaan media dasar MS modifikasi cenderung menghasilkan jumlah ubi yang lebih rendah daripada penggunaan media MS.

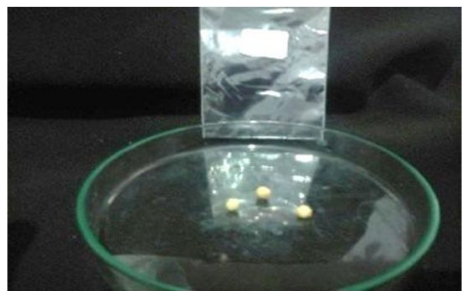

(a)

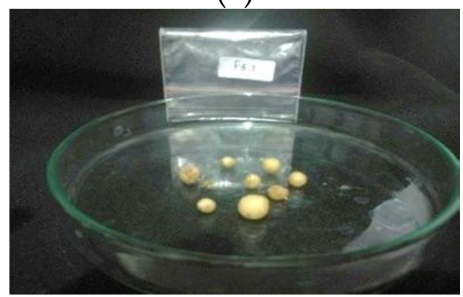

(b)

Gambar 4. Perbandingan Antara Perlakuan Perlakuan F (a) dan Perlakuan L (b).

Pemberian paklobutrazol berpengaruh terhadap jumlah ubi yang terbentuk, peningkatan paklobutrazol sampai konsentrasi sekitar $0.4 \mathrm{mg} . \mathrm{L}^{-}$ 1 dapat meningkatkan jumlah ubi yang terbentuk dan setelah itu adanya peningkatan konsentrasi dapat menyebabkan jumlah ubi yang terbentuk menurun (Samanhudi dkk., 2002).

Tabel 3. Pengaruh Berbagai Kombinasi Zat Retardan terhadap Bobot Ubi Mikro yang Terbentuk.

\begin{tabular}{cc}
\hline Perlakuan & Bobot Ubi Mikro $(\mathrm{g})$ \\
\hline A & $0,033 \mathrm{a}$ \\
B & $0,021 \mathrm{ab}$ \\
C & $0,009 \mathrm{bc}$ \\
D & $0,005 \mathrm{c}$ \\
E & $0,011 \mathrm{bc}$ \\
F & $0,011 \mathrm{bc}$ \\
G & $0,013 \mathrm{bc}$ \\
H & $0,013 \mathrm{bc}$ \\
I & $0,012 \mathrm{bc}$ \\
J & $0,012 \mathrm{bc}$ \\
K & $0,011 \mathrm{bc}$ \\
L & $0,004 \mathrm{c}$ \\
\hline
\end{tabular}

Keterangan: Nilai rata-rata perlakuan yang diikuti oleh huruf yang dan pada kolom yang samamenunjukkan tidak berbeda nyata berdasarkan uji jarak berganda Duncan pada taraf $5 \%$.

Bobot Ubi Mikro. Pengamatan bobot ubi mikro kentang dilakukan pada umur planlet 12
MST (Tabel 3.), ketika tanaman sudah mulai berwarna cokelat dan ukuran ubi mikro kentang sudah cukup membesar siap untuk dikeluarkan dari planlet.

Tabel 3 menunjukkan bahwa rata-rata bobot ubi mikro pada semua perlakuan cenderung tidak berbeda nyata, namun bobot ubi mikro yang relatif lebih tinggi terdapat pada penggunaan paklobutrazol pada media dasar MS maupun media MS modifikasi Paklobutrazol juga menghambat biosintesis giberelin yang berfungsi dalam proses pemanjangan sel dan jaringan tanaman (Rademacher et al., 2000).

\section{Kesimpulan}

1. Kombinasi media dasar dan berbagai jenis zat retardan berperan dalam induksi ubi mikro terutama pada jumlah dan bobot ubi mikro.

2. Penggunaan paklobutrazol berpengaruh dalam peubah bobot ubi, sedangkan penggunaan jasmonic acid untuk peubah persentase plantlet membentuk ubi mikro.

\section{Daftar Pustaka}

EL-Sawy A, Bekheet S, Ibrahimaly U. 2007. Morphological and Molecular Characterization of Potato Microtubers Production on Coumarin Inducing Medium. Int. J. Agric\& biol. 9(5):675-680.

Kianmehr B. , M. Parsa, M. Otroshy, M. N. Mohallati, K. Moradi. 2012. Effect of plant growth regulators during in vitrophase of potato microtuber productionJournal of Agricultural Technology Vol. 8(5): 1745-59.

Gunawan, L.W. 1995. Teknik Kultur In Vitro dalam Hortikultura. Penebar Swadaya. Jakarta.

Hasni, V.U., 2014. Respons Pemberian Coumarin Terhadap Produksi Mikro Tuber Planlet Kentang (Solanum tuberosum L.) Varietas Granola. Universitas Hasanudin.

Hoque, M. E. 2010. In vitro tuberization in potato (Solanum tuberosum L.). POJ , 3(1): 7-11.

Huang, S.Q., Bin, J.H., Li, Z.P. 2002. Effects of methyl jasmonate and ABA on the growth of root and hypocotyls of peanut seedling. J. Plant Physiol. mol. Biol. (28): 351-356.

Ilyas, S. 2008.Teknologi Produksi Benih Sayuran, Departemen Agronomi dan Hortikultura. 
Fakultas Pertanian IPB (Institut Pertanian Bogor).

Kanwal A., A. Ali, K. Shoaib. 2006. In Vitro Microtuberization of Potato (Solanum tuberosum L.) Cultivar Kuroda-- A New Variety in Pakistan. Int. J. Agri. Biol., Vol. 8, No. 3: 337-340.

Karjadi, A.K. dan Buchory A. 2008. Pengaruh Auksin dan Sitokinin terhadap Pertumbuhan dan Perkembangan Jaringan Meristem Kentang Kultivar Granola. J. Hort. 18(4):380-384.

Rademacher. 2000. Growth Retardants : Effects on Gibberellin Biosynthesis and Other Metabolic Pathways Annu. Rev. Plant Physiol. Plant Mol. Biol. 2000. 51:501-31

Samanhudi, Ahmad, Amalia dan Reny. 2002. Pengaruh paklobutrazol dan aspirin dalam pembentukan ubi kentang (Solanum tuberosum L.) secara in vitro. Universitas Sebelas Maret.

Saha, S., Ahmed, M., Islam, M.M., Reme, R.N., and Ali, M.R. 2013. Effect ofdifferent levels of sucrose on microtuberization and different substrates on minituber production resulted from potato meristem culture. IOSR Journal of Agriculture and Veterinary Science (IOSR-JAVS) e-ISSN: 2319-2380,p-
ISSN: 2319-2372. Volume 4, Issue 6 (Sep. Oct. 2013), PP 58-62 .www.iosrjournals.org Sayaka B. dan Hestina J. 2011. Kendala Adopsi Benih Bersertifikat Untuk Usaha Tani Kentang. Forum Penelitian Agro Ekonomi. Pusat Sosial Ekonomi dan Kebijakan Pertanian vol. 29(1):27-41.

Soegihartono. 2005. Kajian Kepuasan Petani Dalam Penggunaan Benih Kentan Tidak Bersertifikat di Kota Batu Propinsi Jawa Timur. Master Theses from BIPB. Bogor.

Suminar E., Rizky W.H., Sumadi. 2015. Produksi Meriklon Kentang Varietas Unggul Baru sebagai Upaya Penyediaan Benih Bermutu dan Bebas Virus. Hibah Kompetitif Faperta Unpad.

Ulloa, R.M., Raices, M., MacIntosh, G.C., Maldonado, S., Tellez-Inon, M.T. 2002. Jasmonic acid affects plant morphology and calcium-dependent protein kinase expression andactivity in Solanum tuberosum. Physiol. Plant. 115: 417- 427.

Wattimena, G.A. 1988. Zat Pengatur Tumbuh. PAU-IPB. IPB. 145 hal.

Zhang, Z.H. 2006. Effect of jasmonic acid on in vitro explant growth and microtuberization in potato. BiologiaPlantarum 50 (3): 453456. 